Article

\title{
Argument from Psychological Difference: Why It Makes Sense to be a Scientific Realist than an Instrumentalist
}

Vida Mia S. Valverde

\begin{abstract}
This paper contends that psychological factors of cognition and affect come into play in determining which philosophical framework, scientific realism (SR) or instrumentalism, makes more sense in the practice of science through history. The proposed Argument from Psychological Difference (APD) asserts that the scientific realist has a stronger impetus than the instrumentalist to pursue science that is anchored in existing underlying reality and cognizant of how the human person practices such science. The APD is threshed out in recognizing transcendence as manifested through history; in affirming the human quest for truth and certainty; in the stand that is taken in history when the science is more mature and certain. SR is especially made more comprehensive and coherent when it considers the interplay of the observable and unobservable aspects of reality and of how the human person is in the scheme of things. Scientific realism is the more superior stance compared to instrumentalism because, ultimately, it makes more meaningful sense by being grounded in existing material reality that has the power to move us rather than in convenient fictions that operate on utility.
\end{abstract}

Keywords: cognition, scientific realism, instrumentalism, psychological difference

\section{Scientific Realism, Instrumentalism, and Methodological Indifference}

7 here is a contention that there is no need for choosing scientific realism (SR) or instrumentalism as a philosophical framework with regards to reality. Devitt defines his doctrine of SR as: "Most of the essential unobservables of well-established current scientific theories exist mind

(C) 2020 Vida Mia S. Valverde

https://www.kritike.org/journal/issue 26/valverde june2020.pdf

ISSN 1908-7330 
independently." ${ }^{1}$ On the other hand, instrumentalism, which is a form of antirealism, puts forth that scientific theories and their posited unobservables are instruments for predicting observable phenomena. ${ }^{2}$

One philosophical framework, scientific realism, could just as well serve as an alternative to the other, instrumentalism. If we accept that science aims to provide true explanatory accounts of the phenomena as a realist description, the instrumentalist's description would be the same except that empirical adequacy would substitute for truth. We then believe in the empirical adequacy of predictively successful theories, not in their truth. So if the realist says that science provides true explanatory accounts, the instrumentalist would say that science provides empirically adequate accounts. It has thus been contended that the practice of science shows no distinction at all between a realist outlook and an instrumentalist one. A realist explanation of a scientific practice may be turned into an instrumentalist explanation.

There are no aspects of scientific practice that a realist can explain and an instrumentalist could not. Robin Findlay Hendry, however, argues that the epistemic stance of the scientist, whether realist or instrumentalist, colors her practice. ${ }^{3}$ Hendry refers to a historiographical intuition that suggests that realism or instrumentalism influences what practices scientists employ but Arthur Fine and André Kukla propound that realism and instrumentalism are indifferent to the practice of science. ${ }^{4}$ There is explanatory indifference which implies that for every realist explanation of the success of a scientific practice there is also an instrumentalist explanation of its success. There is the motivational indifference which implies that for every realist reconstruction of a scientific practice there is also an instrumentalist reconstruction. In the former, the phenomena to be explained involve the success of scientific theories. In the latter, the phenomena to be explained are the scientific practices themselves.

These two types of indifference stem from Fine's metatheorem to support his claim that arguments based on the ability of scientific realism to explain certain aspects of scientific practice do not provide support for realism to be a better stance against instrumentalism: if the phenomena to be

1 Michael Devitt, "Scientific Realism," in The Oxford Handbook of Contemporary Philosophy, ed. by Michael Smith and Frank Jackson (New York: Oxford University Press, 2007), 769.

2 Michael Gardner, "Realism and Instrumentalism in Pre-Newtonian Astronomy," in Testing Scientific Theories, ed. by John Earman (Minneapolis: University of Minnesota, 1983), 238.

${ }^{3}$ See Robin Findlay Hendry, "Are Realism and Instrumentalism Methodologically Different?" in Philosophy of Science, 68:3 (Supplement, 2001), S25-S37.

4 See Arthur Fine, "Unnatural Attitudes: Realist and Instrumentalist Attachments to Science," in Mind, 96 (1986), 149-179; André Kukla, Studies in Scientific Realism (New York: Oxford University Press, 1998).

(C) 2020 Vida Mia S. Valverde

https://www.kritike.org/journal/issue 26/valverde june2020.pdf

ISSN 1908-7330

(c) ) BY-NC-ND 
explained are not realist-laden, then to every good realist explanation there corresponds a better instrumentalist one. ${ }^{5}$ Hendry, however, holds that a practice one finds rational to involve oneself in is different from being motivated to actually engage in the practice. The explanatory indifference may find merit but not the motivational indifference. It can happen that the explanatory indifference of realism and instrumentalism may also bring about motivational indifference. There are corresponding realist and instrumentalist reconstructions to the realist and instrumentalist explanations. Fine's metatheorem, however, does not afford an instrumentalist explanation for every phenomenon, only for those that are not realist-laden. Realist-laden here means having beliefs and inferences available only to the realist. Even if the instrumentalists do not have the inclination to recognize such realist-laden phenomena, they can still acknowledge realist-laden practices. Though instrumentalists may find merit in the explanatory indifference, they do not need to accept the motivational indifference.

The difference between the explanatory and motivational types of indifference further gives credence to the irreconcilability of the realist and instrumental accounts of science. The efforts to find a working compromise between the two epistemic stances do not result in a coherent and consistent outlook that satisfies both sides of the debate. Neither does the collapse of scientific realism into instrumentalism or vice-versa hold merit. There can be a choice of one over the other and this is rooted in the human person's hankering and hungering for a truth that one can really hold on to and stick one's neck out for. The reality that science is a continuously evolving field does not make belief and acceptance of theoretical entities an exercise in futility. Theories and their posited unobservables may later be proven false but we are not wrong in positing them. Sticking only to the observables of the instrumentalists lets us miss a great part of reality.

\section{Argument from Psychological Difference (APD)}

The lack of motivational indifference established in the previous section points to an integral facet of the human person as a psychological being that operates mentally and intellectually as a function of awareness, feeling, or motivation. Cognitions and affect color our decisions and action. Cognition refers to conscious and analytical evaluation of a situation. Affect concerns emotions and feelings. APD contends that such psychological factors come into play in the evaluation of a framework. Material content is not sufficient basis from which a philosophical stance is taken. Even if there

${ }^{5}$ Arthur Fine, “Unnatural Attitudes," 154.

(c) 2020 Vida Mia S. Valverde

https://www.kritike.org/journal/issue 26/valverde june2020.pdf

ISSN 1908-7330

(cc) BY-NC-ND 
may be explanatory indifference between instrumentalism and scientific realism, motivational indifference does not necessarily follow because the human person is driven by different psychological factors that are attractive to her sense of self as a being in the world. There are psychological differences upon which she tackles and takes certain stances. Instrumentalism and scientific realism may both provide rational frameworks from which to understand phenomena. It would just as be perfectly reasonable to be a scientific realist or an instrumentalist in order to apprehend and comprehend the world. There are, however, psychological underpinnings that favor one framework over the other.

A scientific realist has a different psychological impetus from that of an instrumentalist. Knowing that there is an underlying reality and existence to be uncovered, the scientific realist is more compelled than the instrumentalist to pursue it to its brute core. If instrumentalism were right, it would be appropriate for the scientist to be complacent about his theory as long as it was working on the surface. ${ }^{6}$ The atheistic instrumentalist does not have an underlying reality that one can stick out one's neck for. The APD affirms the strength of scientific realism over instrumentalism because it supports a holistic reality that takes into consideration how the human person acts and decides given her place in the larger scheme of things. This argument takes into consideration the human person's recognition of transcendence, the human quest for truth and certainty, and the need to make meaningful sense out of any human undertaking. This argument holds that our mental activities and frameworks are molded not just by logical material content but by a deeper sense of awareness of self and reality. APD acknowledges the back and forth between person and reality. It is not solely contingent on the human person but is appreciative of the natural stirrings within of the person as she makes her way in the world.

\section{Scientific Realism as Recognition of Transcendence}

It is more rational to believe in scientific realism than in instrumentalism because it is in congruence with the way we think and discover more about the world. We look for what underlies our experience of the world. Bernard Lonergan expresses that the rationally conscious enters a dynamic state in which dissatisfaction with mere theory manifests itself in a demand for a fact, for what is so. ${ }^{7}$ There is a driving insight to discover beyond what is observable. We are struck by insight in our inquiries and investigations about the world and we make a judgment that there is an

${ }^{6}$ Michael Devitt, Realism and Truth ( New Jersey: Princeton University Press), 131.

7 See Bernard J.F. Lonergan, Insight: A Study in Human Understanding (New York: Philosophical Library, Inc., 1956).

(c) 2020 Vida Mia S. Valverde

https://www.kritike.org/journal/issue 26/valverde june2020.pdf

ISSN 1908-7330

(c) $)$ BY-NC-ND 
underlying existing reality and make the decision to commit to such reality. Scientific realism lets us go beyond the capacity of our senses and triggers the insight that points us to uncover further aspects of reality that are seemingly mysterious. From observable phenomena, there is a movement and recognition of different, perhaps richer, reality.

Recognizing the existence of the unobservable seems like holding to a transcendence ${ }^{8}$ which is not a regular aspect of science. It is transcendence in that it takes insight to appropriate it. It is transcendence in the sense that it goes beyond and is not defined by science. Instead, science improves our access and understanding of such transcendence. History of science shows how we know more and more about the unobservable. The unobservable is not just a convenient fiction we posit to make sense of the observed phenomena. The realist, in effect, deals with transcendence. On the other hand, the instrumentalist deals with convenient fictions that systematize his experience of the world.

Weighing between transcendence and convenient fictions is a choice between scientific realism and instrumentalism. If we delve deeper, the realist transcendence is more meaningful than the instrumentalist convenient fictions. Having something real underlying observed phenomena is a better explanation than having a convenient fiction. Even if instrumentalism provides useful information, it limits our knowledge by defining our knowledge within the parameters of usefulness. Reality is then reduced to what is pragmatic, to what makes theories work.

The process and history of science and human knowledge cannot be divorced from technology. The human person develops technology that helps him discover more about the world. The feudal culture of the Middle Ages that was rife with superstition progresses into a culture where the scientific method is a means of understanding the world better. Scientific realism, in a sense, is a product of the advance of technology. What is uncovered and discovered of the world through technology may not be immediately useful, but it is still knowledge that represents reality.

The accumulation of knowledge throughout history is not only an accumulation of well-functioning posits that save the phenomena. There is a building of the picture of the world through time and the scientific method that continuously builds it operates with the recognition that there is an underlying reality that girds observable reality. Our knowledge and picture of the world develop in an upward spiral where new knowledge builds on previous knowledge to come up with something more synthetic, comprehensive, and consequently, elevated understanding of the world. It

${ }^{8}$ Transcendence is not taken in the sense of the spiritual but in the sense of going beyond the limits of ordinary experience and inherited concepts. 
will only be a matter of time when this underlying reality comes to the fore with advances in technology.

History shows that reality impinges on the human person whether she likes it or not, affirming the existence and independence dimensions propounded by Devitt. Furthermore, history affirms that material reality and idea are joined. The more we discover matter, the more we have ideas; that there is indeed a world, though currently unobservable, that triggers insight and gives knowledge. Such materialist philosophy grounds scientific realism and imbues it with a rationality that is not found in the same extent in instrumentalism.

The rationality of scientific realism is borne out in history, in the evolution of how we know more and understand the world we live in. The scientific realism-instrumentalism debate cannot just be settled through armchair theorizing but more so through looking at established history. Having this picture of scientific realism in history exhibits the theoretical virtue of comprehensiveness. There is a holistic understanding of the different aspects of reality and how they work together as a whole. Matter, transcendence, history, knowledge, reality, and the scientific method all come into play with each other and lend greater strength and rationality to scientific realism. Physical substance existing in space and time is apprehended by the human person who further realizes that such physical substance means and points to something more. Just as the human person is a physical substance who is something more than what is observed of her, she intuits the same of the matter that she observes, of the world she lives in. In time, refinement of knowledge ceaselessly occurs because reality keeps on unveiling more of itself with the development of science and technology. Such intertwining of the different facets of existence makes for a richer philosophical framework that encompasses a larger spectrum of reality than instrumentalism ever will.

With greater value of comprehensiveness in scientific realism than in instrumentalism, the former is the more viable position to take.

\section{Human Quest for Truth and Certainty}

In asserting that one can have knowledge of the scientific unobservables, scientific realism may be engaging in a metaphysical speculation that runs counter to the practice of empirical science. Scientific realism as this empirical hypothesis that scientific theories are true and the entities they postulate are real looks as if it is dealing with straightforwardly scientific question and has nothing to do with philosophizing. The philosophical dimension comes in when philosophers add their interpretations on the methods and results of science. The theories, 
observable facts, modes of inference, and other aspects of the scientific method as accepted and used by the scientific establishment plus the interpretations of the philosophers call for philosophizing. Instrumentalists add on their interpretation of accepted scientific theories as tools for prediction and control of the environment. Realists add on their interpretation of accepted scientific theories as true descriptions of the world. The former holds on to what works or has utility while the latter holds on to what is true. There is the tension between what is empirically adequate and what is true. Truth for instrumentalism is not an ideal to be striven for. Truth for scientific realism can be held on to even if Devitt asserts that the issue of truth is not constitutive of scientific realism.

Laudan writes that we would like to think that science works because it has got a grip on how things really are. ${ }^{9}$ This grip happens because there is something to hold on to. There is a truth to be gripped; there is an existence to be gripped. Our world develops constantly, so does philosophy, and most especially, so does science. Science, with all its changes and developments, has become an influential institution from which we view the world. Is it enough for us that what we can hold on to is empirically adequate and thus, works and gives results? Or must there be truth, though an ideal, that lets us have a grip on the world? The truth that is spoken of here is not a sophisticated conception that is arrived at through the different theories of truth- correspondence theory, semantic theory, coherence theory, pragmatic theory. It is a functional conception of truth that something is, that something is real; the truth that a non-specialist in philosophy would understand.

Sankey's statement of the first core doctrine of scientific realism which is aim realism is that the aim of science is to discover the truth about the world. ${ }^{10}$ Progress of scientific theories moves us closer to the truth. Science as an ongoing historical progress is still far from reaching such aim of truth. Current scientific theories, at best, may be close to the truth or they may be approximately true. This is in contrast to the claim of instrumentalism that scientific theories are neither true nor false. The truth that science seeks is of an explanatory nature and is also that which is discovered by science. It is not something that we construct or invent or manipulate.

It must be recognized, however, that giving a true account of what the world is like, no matter how scientific the process, will always have a metaphysical aspect that goes beyond experience. With Devitt's scientific realism being a metaphysical doctrine, as earlier mentioned, human

\footnotetext{
${ }^{9}$ See Larry Laudan, "A Confutation of Convergent Realism," in Philosophy of Science: The Central Issues, ed. Martin Curd and J. A. Cover (New York: W.W. Norton \& Company, Inc., 1998), 1114-1135.

10 See Howard Sankey, Scientific Realism and the Rationality of Science (Hampshire: Ashgate Publishing Limited, 2008).
} 
inhabitants of the world speculated upon are relevant objects of analysis and reflection. It is an exigency of being that the human person seeks for a truth. What works or has utility is not sufficient. If the theories produce results and predict phenomena, the instrumentalist can already live with that. This pragmatic stance asserts that there is no need for truth. It is an ideal that is not needed or may not be even reached at all.

Though scientific realism asserts that it is able to give true descriptions about the world, there is also an implicit recognition that such truth is asymptotic. One cannot really reach the limit, the ideal; one can only approximate. The closer one approximates the truth, the better. This does not mean, however, that aiming and wanting to hold on to a truth is an exercise in futility. Instrumentalism appreciates that there is uncertainty in scientific theorizing and chooses to stick with what works. Truth, in effect, is not given up as an ideal but because it is ideal that it is given up. Nevertheless, it is still a standard we try to compare with what has been achieved so far and get close to as much as possible. It is not something we tend to be agnostic or atheistic about in scientific theorizing and experimentation. It is also not the Wittgensteinian truth which must always be conceived to lie within the bounds of attainable knowledge or linguistic expressibility. ${ }^{11}$

Aristotelian metaphysics states that all men desire to know. There is this Kantian exigency of being that we want truth and the certainty that comes with it. Such is exemplified in scientific realism. Even as theories change and evolve, there is truth that is not just empirically adequate but something one can stick out one's neck for. It seems that even when it comes to taking a stand about scientific realism and instrumentalism, the tenet that nature abhors a vacuum still holds. Anytime there is a lack, nature rushes in to fill it up. Where there is lack of certainty, one wants certainty. Where there is ignorance, one desires to know. Settling with what gives the results is not just enough. This is a transcendental ideal in that it is a norm that governs but cannot be really proven. This may seem as if it runs counter to Devitt's physicalist and naturalist philosophy, but it provides a ground for the rationality of scientific realism. It is still also in the realm of first-order issues in ontology. Devitt always urges to put metaphysics first. To try to address scientific realism in terms of second-order issues of language and reference is putting the cart before the horse. According to Devitt,

Realism is an overarching empirical (scientific) theory or principle. It is initially plausible. It is supported by arguments that make no appeal to theories of language

\footnotetext{
${ }^{11}$ Christopher Norris, On Truth and Meaning: Language, Logic, and the Grounds of Belief (London: Continuum International Publishing Group, 2006).

(c) 2020 Vida Mia S. Valverde https://www.kritike.org/journal/issue 26/valverde june2020.pdf ISSN 1908-7330
}

(c) BY-NC-ND 
or understanding .... What firmer place could there be to stand than Realism, as we theorize in such undeveloped areas as those of language and understanding? In contrast, the poor state of theories in those areas, whether verificationist or not, makes them a bad place from which to start theorizing, particularly in determining overarching principles about the nature of reality. To think otherwise is to put the cart before the horse. ${ }^{12}$

Devitt's scientific realism is primarily metaphysical and to refocus the issues of truth, rationality, and knowledge towards a philosophy of language with referent and semantic concerns is getting the priorities wrong. Central to his arguments for realism is that the metaphysical doctrines can and must be disentangled from all epistemic and semantic issues. When faced with the question, what has truth got to do with realism, Devitt states "On the face of it, nothing at all. Indeed, Realism says nothing semantic at all beyond, in its use of 'objective', making the negative point that our semantic capacities do not constitute the world." 13 Though truth is not a constitutive of Devitt's realism, it is an anchor for realism in that we believe that truth is what ultimately explains. With instrumentalism, the question of truth is not relevant to theorizing and scientific evaluation. What is important is that the observable consequences of the theories are in consonance with experience. Truth belongs only to the observational parts of theories for instrumentalism.

\section{Scientific Realism Makes Meaningful Sense}

J.J.C. Smart speaks of philosophy and the elimination of nonsense. ${ }^{14}$ Together, philosophy and science endeavor to have a comprehensive and meaningful view of the world. Both science and philosophy share a tentative character and we must thus not rest easy on the supposed laurels of each because the so-called final truth will always be at the horizon, and we hope that both will bring us closer to such truth. It has been argued that certain quarters of philosophy are not concerned, as scientists are, between truth and falsity, but with that between sense and nonsense. ${ }^{15}$ Such is put to the fore with the viewpoint of instrumentalism. Whether what is posited is true or false is not the issue in contention. One might think then that instrumentalism

\footnotetext{
${ }^{12}$ Devitt, Realism and Truth, 284.

${ }^{13}$ Ibid., 39.

${ }^{14}$ See J.J.C. Smart, Philosophy and Scientific Realism (London: Routledge \& Kegan Paul, Ltd., 1963).

${ }^{15}$ Ibid., 3.
}

(c) 2020 Vida Mia S. Valverde https://www.kritike.org/journal/issue 26/valverde june2020.pdf ISSN 1908-7330 
falls under the category of making sense. It is neither true nor false; it just makes sense because it makes the theories work.

Smart asserts that philosophers, together with scientists and historians, must ensure that we do not fall into nonsense. Nonsense must be eliminated. This nonsense, Smart says, has not even achieved the distinction of an intelligible falsehood. ${ }^{16}$ At the very least, one must be able to express an utter falsehood, not a nonsense masquerading as a truth, especially when such nonsense is dressed up in seemingly technical and intelligent language. It may be too simplistic, but it seems that instrumentalism is flirting with nonsense.

It is intelligible in the sense that it makes us grasp what needs to be grasped given limited knowledge and resources; but it is unintelligible in the larger scheme of the interplay of science, humanity, and the world. The fact that philosophy is also more than just the elimination of nonsense, ${ }^{17}$ then it is but right that we look far beyond the logic that is found in the technical such as language and data. This is precisely what we do when we look at the scientific realism-instrumentalism debate as a human person in the world doing science. If we endeavor to "grasp the whole range of reality, the whole person must be involved in the act of philosophizing... must accommodate the various aspects of reality within an integrated whole." 18 This integrated whole encompasses the unobservable, the observable, the human person practicing science in the world, and the practice of science in history. We do not deem extraneous that which exceeds our apprehension, that which goes beyond our natural and technological capacities. The integrated whole recognizes that which is not immediately material and quantifiable but, at the very least, impinges on our consciousness.

We want to understand the world we inhabit not just so we can deal with it but also because we want to become better versions of ourselves. Interestingly, we become better versions of ourselves when we take on the materialist metaphysics of Smart that allows us to recognize that the human person is part of nature, not above or better than it. When we appreciate being part of nature, we do not destroy it. This materialist metaphysics checks the arrogant notion that man is the measure of all things. Such philosophical clarity and scientific knowledge make us recognize that we are not at the center of the cosmos from which all reality revolves. Seen and unseen, the reality is out there for us to discover and uncover using our best science. This reality is not constructed nor invented. What is of note in Smart's materialist metaphysics is that from his conception of the human person as just a

${ }^{16} \mathrm{Ibid} ., 4$

17 Ibid., 8.

${ }_{18}$ Rainier Ibana, Solidarity and Social Analysis (A Disseration on Max Scheler's Social Philosophy) (Quezon City: Sublime Paralytic Publications, 1993), 58.

(c) 2020 Vida Mia S. Valverde

https://www.kritike.org/journal/issue 26/valverde june2020.pdf

ISSN 1908-7330

(cc) BY-NC-ND 
complicated physical mechanism that is part of nature, his realist thought encompasses the nature of unobservables such as electrons to a human person's ethics. Scientific realism then is deemed integrative of the multiple aspects of reality, of which the human person is only a part of.

\section{Instrumentalism, Scientific Realism, and the Maturity of a Science}

Gardner suggests that a blanket interpretation of all theories from a scientific realist or instrumentalist perspective should not be the case as different theories may need different treatments. History of science has exhibited a pattern wherein a theory is first put forward or accepted as a calculational device and then later comes to be regarded as literally true. One starts from an instrumentalist interpretation and later on ends with a scientific realist one. This was evident in the transition of the Copernican theory from an instrumentalist interpretation to a realist one. The Copernican theory was recognized and accepted by the astronomers of his time as credible in its explanation of the movement of the heavenly bodies by taking away, among other things, use of the equant, a mathematical concept developed by Ptolemy in $2^{\text {nd }}$ century AD to account for the observed motion of the planets. Melanchthon (1497-1560) of the University of Wittenberg praised and used parts of Copernicus's theory in his studies but still ultimately refused accepting the theory on realist terms because it conflicted with Scriptures and Aristotelian doctrine of motion. ${ }^{19}$ As evidence grew, acceptance of the heliocentric Copernican theory came by way of a realist viewpoint.

The practice of science has shown that scientists sometimes believe a theory is true and sometimes that it is only empirically adequate. There seems to be a need to identify the conditions in which it would be reasonable to use an instrumentalist or a realist interpretation. As the scientist grows in certainty about his postulates, he tends to become realist. As he does more experiments and manipulates the electron in a variety of ways, he commits to a particular existence of an electron. Again, there is this movement towards the truth even if what already works is sufficient.

Though a definitive survey of the operating frameworks of scientists will shed further light on whether the practice of science is largely realist or instrumentalist, it will be mostly addendum material to the argument from discovery and argument from psychological difference. Theoretical physicist and professor Edward Redish, who is also the main proponent of the Maryland Physics Expectations Survey (MPEX) that assesses expectations, beliefs, and attitudes of students towards learning calculus-based physics,

${ }^{19}$ Gardner, “Realism and Instrumentalism in Pre-Newtonian Astronomy,” 260.

(c) 2020 Vida Mia S. Valverde

https://www.kritike.org/journal/issue 26/valverde june2020.pdf

ISSN 1908-7330

(cc) BY-NC-ND 
affirms that no such survey of scientists has been undertaken by the Maryland Physics Education Research Group. In an email correspondence with Redish on 29 December 2014, he expresses that the difference between instrumentalism and scientific realism is a "difference that does not make a difference." 20 One must choose one's axioms and work with them. Though Redish seemed to shrug off the difference between scientific realism and instrumentalism, the first epistemological axiom he identifies as fundamental to what he knows as a self-confessed scientific rationalist is: There is a real world independent of human observation. ${ }^{21}$ As a scientist, Redish may not care or reflect about the ramifications presented by the philosophical stances of scientific realism and instrumentalism, but the primary axiom he operates with certainly speaks of scientific realism.

Devitt's conception of scientific realism is entity realism wherein most of the essential unobservables of well-established current scientific theories exist mind-independently. ${ }^{22}$ If this is the crux of his philosophy, then establishing the reality of the controversial unobservables is key. Whatever else theorizing about scientific realism and instrumentalism, the core of the matter still lies in settling the score in the realm of the unobservables. Hacking asserts that experimental physics provides the strongest evidence of scientific realism. ${ }^{23}$ Unobservables are manipulated to give rise to new phenomena and to study other aspects of the world. They are tools not in the sense of convenient fictions and systematizing phenomena but tools for actually doing and manipulating. Case in point: the electron was a hypothetical entity first but as its causal powers are better understood and it is used to build devices, it no longer remains hypothetical. Its status has changed in that the experimenter now becomes a realist about such an unobservable. It is no longer just about finding the demarcation between the theoretical and unobservable and finding that it is ontologically insignificant; but elevating the theoretical to the real because it can be directed, controlled, and experimented upon.

From the human person's pursuit for a truth, to establishing the truth and logic of theories, to handling and experimenting on an unobservable to establish its reality, it cannot be denied that taking on the scientific realist viewpoint is the more rational and valid stance. Much as there are sophisticated versions and variations of instrumentalism, from the traditional conception that theories are instruments for systematizing phenomena in

\footnotetext{
${ }^{20}$ Edward Redish, email message to the author, 29 December 2014.

21 Edward Redish, "Axioms," in The Unabashed Academic (27 June 2010), $<$ http://theunabashedacademic.blogspot.com/2010 0601 archive.html $>$.

22 Devitt, "Scientific Realism," 767.

${ }^{23}$ See Ian Hacking, Representing and Intervening: Introductory Topics in the Philosophy of Natural Science (Cambridge: Cambridge University Press, 1983).

(c) 2020 Vida Mia S. Valverde

https://www.kritike.org/journal/issue 26/valverde june2020.pdf

ISSN 1908-7330
}

(cc) BY-NC-ND 
pragmatically useful ways to the contemporary interpretation that theories are not merely conceptual devices in the service of pragmatic ends but correct or incorrect representations of unobservable entities and processes, ${ }^{24}$ it still does not do justice to the whole enterprise of science as a great human endeavor that seeks to understand, explain and better the world. Instrumentalism lets us be empirical and scientific. We, however, hunger for the real that is not fully encompassed by instrumentalism. Philosopher of science Michela Massimi, 2017 recipient of the Wilkins-Bernal-Medawar Award from UK's Royal Society expresses,

I personally believe that a realist viewpoint can include our ability to carve out the space of what might be objectively possible in nature, rather than in terms of mapping onto some actual states of affairs.

Progress here is not just about discovering a new particle. It is also-indeed, most of the time-being able to carve out the space of what might be possible in nature with high confidence. ${ }^{25}$

The scientific enterprise is made more meaningful because we are compelled to "carve out the space of what might be possible in nature." Such appreciation of possibility is twofold. It shows what is possible in the human person practicing science in that she pushes limits to uncover what is hidden in nature. It shows what is possible in nature in that it allows nature to be unveiled in its confounding mysteries and complexities, not just in what saves phenomena.

Armchair theorizing and philosophizing view the rationality and validity of instrumentalism. The test, however, of the pudding is in the eating; and eating comes by way of scientific practices and experimentation and the human inclination. A theory may start from an instrumentalist framework but as it gets tested and grows in maturity, it evolves to something more real and certain and literally describes what is in the world. A theoretical entity loses its hypothetical status when the scientist directs and controls it to react, interact, and interfere with the world it is in. No longer is this unobservable a conceptual tool but something literally real. "Interference and interaction are the stuff of reality," declares Hacking. It is one thing to "see" things under a microscope or any detecting and monitoring instrument. It is greater and

${ }^{24}$ Jarrett Leplin, A Novel Defense of Scientific Realism (New York: Oxford University Press, 1997), 105.

${ }^{25}$ Michela Massimi, "Questioning Truth, Reality, and the Role of Scientific Progress," interview by Philip Ball, in Wired (2 June 2018), <https://www.wired.com/story/questioningtruth-reality-and-scientific-progress/>. 


\section{ARGUMENT FROM PSYCHOLOGICAL DIFFERENCE}

confirmatory of reality when what is viewed can be manipulated, e.g., We stain the specimen, slice it, inject it, irradiate it, fix it. ${ }^{26}$ In addition, to distinguish the salivary gland of a fruit fly and a dust particle when looking through a microscope, one must already have had experience dissecting a fruit fly under a microscope of moderate magnification and experience manipulating different microscopes. ${ }^{27}$ There is always this element of doing that is integral to grasping the unobservable. As Chang puts it, "even the most abstract aspects of science are rooted in doings." 28 The abstract, unobservable, and theoretical is made real in our doings, in our epistemic activities. An epistemic activity is a more or less coherent set of mental or physical operations that are intended to contribute to the production of improvement of knowledge in a particular way, in accordance with some discernible rules though the rules may be unarticulated. ${ }^{29}$ Such is the science we perform, and it is constantly developing to enable us to manipulate more of what is unobservable. The human person involved in the great enterprise of science necessarily seeks for a truth that underlies his understanding of the past, present, and future.

From the discussion above, scientific realism is the proper stance when the science is mature and instrumentalism when the science is still in its early stages. It is as if instrumentalism is an ad hoc framework until science and technology become mature enough to warrant a full-on scientific realist view. Looking at the debate from this kind of reasoning would show that scientific realism is the more rational and coherent position because it rests on a well-confirmed science. Such thinking, however, could mean that being a scientific realist or instrumentalist depends upon the maturity of science which is not the case. One is still a scientific realist whether a posited theoretical entity turns out to be wrong or inexistent. One is still a scientific realist whether the science is mature or not. What is significant in this line of reasoning is that the stronger the science, the stronger is the case for scientific realism. This is history showing the strength of a scientific realist framework. This retrospection is affirming that operating within the view that there is an underlying existence to observable phenomena is ultimately backed up by mature science.

Both scientific realism and instrumentalism may give working results and explanations. Their significant difference comes in when science and

\footnotetext{
${ }^{26}$ Hacking, Representing and Intervening, 168.

${ }^{27}$ Ian Hacking, "Do We See Through a Microscope?" in Images of Sciences: Essays on Realism and Empiricism, ed. by Paul M. Churchland and Clifford A. Hooker ( Chicago: University of Chicago Press, 1985), 136.

${ }^{28}$ Hasok Chang, "Epistemic Activities and Systems of Practice," in Science After the Practice Turn in the Philosophy, History, and Social Studies of Science, ed. by Léna Soler, Sjoerd Zwart, Michael Lynch, and Vincent Israel-Jost (New York: Routledge, 2014), 76.

${ }^{29} \mathrm{Ibid} ., 72$.

(c) 2020 Vida Mia S. Valverde

https://www.kritike.org/journal/issue 26/valverde june2020.pdf

ISSN 1908-7330
}

(cc) BY-NC-ND 
technology eventually prove existence of unobservables underlies the observable. The conceptual convenient fictions can no longer be when one is confronted by material reality brought about by the best science and technology.

\section{The Point of Devitt}

Devitt's stand on scientific realism depends on distinguishing it from other doctrines and on choosing the right place to start the argument. This is evident when he lays down his maxims at the beginning of Realism and Truth (1991). Coming from a naturalist perspective, Devitt urges that the issue of realism must be settled first before moving on to epistemology and semantics. Using a priori epistemology or a priori semantics first, realism collapses.

He says that when we approach our metaphysics empirically, realism is irresistible. ${ }^{30}$ We end up with a better empirical semantics and empirical epistemology that build on the metaphysics that was properly prioritized. Other philosophers contend that metaphysical realism be approached via semantic or empirical realism. It cannot be denied that all three approachesmetaphysical, epistemological, and semantic- are intertwined, and the philosophy of language may help clarify the realist and instrumentalist issues, but it will not really settle the metaphysical issue.

Devitt disentangles the semantic issue of truth from the metaphysical issue of realism. In a sense, this makes for clear and delineated thinking. Though Devitt separates truth from realism, he defends a "robust correspondence notion explained in terms of reference." 31 Devitt's definition of the realist correspondence theory of truth rests on the fact of a mindindependent reality. This strict delineation of metaphysical issues from the semantic and epistemological ones is helpful for the sake of clarity in thinking. Life and the world, however, do not allow for such marked boundaries. An effective defense of scientific realism will necessitate interplay of the different domains of realist issues, but Devitt sets a stable ground from which other issues spring.

No matter the uncertainty in having a scientific realist stand, this is still what best exemplifies the human person's pursuit for a comprehensive picture of the world.

Wilfrid Sellars states, "Our aim is to manipulate the three basic components of a world picture: (a) observed objects and events, (b)

${ }^{30}$ Michael Devitt, "A Naturalistic Defense of Realism," in Metaphysics: Contemporary Readings, ed. by S.D. Hales (Albany: Wadsworth Publishing Company, 1999), 96.

${ }^{31}$ Devitt, "Scientific Realism," 28.

(c) 2020 Vida Mia S. Valverde

https://www.kritike.org/journal/issue 26/valverde june2020.pdf

ISSN 1908-7330 


\section{ARGUMENT FROM PSYCHOLOGICAL DIFFERENCE}

unobserved objects and events, (c) nomological connections, so as to achieve a maximum of 'explanatory coherence.'" In this reshuffle no item is sacred." 32

The components of existence come together to give a coherent and comprehensive picture of the world. The observed, unobserved, and the inherent and lawlike underpinnings of reality comprise the most primal elements of our human existence. They span the spectrum of our reality and to be cognizant of all these fulfills our imperative for wholeness and truth. Manipulating these elements characterizes our scientific endeavors. Manipulating these elements give explanatory coherence to who we are as beings existing in space and time. BonJour states, "Intuitively, coherence is a matter of how well a body of belief 'hangs together': how well its component beliefs fit together, agree or dovetail with each other, so as to produce an organized, tightly structured system of beliefs, rather than either a helterskelter collection or a set of conflicting subsystems." 33 The 'hanging together' of the primal elements of our existence makes for an integrated whole that makes sense in the world we live in and how we operate in this world.

Science, as a human and analytical endeavor, is not contented with what works when there is still a horizon that points to a more, to that which is integrative. It can be contented because it recognizes its limits but not because convenient fictions have become inconvenient. No item is indeed sacred in our consideration of the world because we recognize the richness that is found in the unobservable, even if we cannot be fully empirical about the whole of reality.

There is a certain poetry in science when there is something else going on that meets the eye, when we are sensitive to imperceptibles. When machines that are supposed to detect unobservables register zero detection, it is concluded that such unobservables are 'below detection' not that they are inexistent. Such imperceptibility provides a nuance that something not perceived is there, even if barely there. We are then driven to unconceal the imperceptible. That is how we are. It is integral that the different facets of our reality cohere with who we are and our endeavors to make sense of things. BonJour starts his passage above with 'Intuitively' in recognition of our subtle and reflex knowing of things that make us whole, even if we are lacking empirical basis. It is intuitive for us to acknowledge unobservable reality as part of our reality. It is intuitive for us seek how the different facets of existence hang together and not remain with the delineated empiricism that instrumentalism mandates. Instrumentalism impoverishes us as it "regards

356.

32 Wilfrid Sellars, Science, Perception, and Reality (New York: Humanities Press, 1962),

33 Lawrence BonJour, The Structure of Empirical Knowledge (Cambridge: Harvard University Press, 1985), 93.

(c) 2020 Vida Mia S. Valverde

https://www.kritike.org/journal/issue 26/valverde june2020.pdf

ISSN 1908-7330

(cc) BY-NC-ND 
science as a strictly practical endeavor that does no more than guide our expectations and canalize our interventions in the world." 34

In a talk of Devitt held on 19 September 2014 at the City University of New York, he stressed his basic argument that realism explains observed phenomena as opposed to the success argument that realism explains the observational success of scientific theories. ${ }^{35}$ Though he has always put forth the success and basic arguments as strong arguments for scientific realism, he recently declared that the basic argument is stronger and not open to criticisms unlike the success argument. This recognition of the basic argument points to having a perspective that is grounded in the more fundamental what is. This basic argument further highlights how science is implemented with a realist framework in that convenient fictions are not just posited to explain observed phenomena but that there is something existing out there that explains observed phenomena.

More than being entity realism, Devitt's scientific realism teaches us to give priority to what is. It arises from the age-old question, "What ultimately is there, what is it like?" The answer then gives us a grasp of the richness of reality that encompasses both the observable and unobservable. The linguistic turn in philosophy in the $20^{\text {th }}$ century does not take away relevance of SR especially when there is such a cacophony of positions that vie for attention. This cacophony is made louder and confusing when positions come from theories of language and truth that do not constitute realism at all. Semantics is a weak place to start because the theory of language focuses on a very small part of the world, its people. Semantics cannot answer what there is and what it is like. A scientific realism that can withstand the onslaught of antirealism is first metaphysical.

Though there may be contentions that scientific realism and instrumentalism eventually collapse into each other and give the same results, this paper shows otherwise with its explication of the argument from psychological difference.

Scientific realism provides a more robust accounting of unobservable reality than instrumentalism. It is respectful of the complexity of reality that is beyond the maneuverings and machinations of the human person. The strength of scientific realism over instrumentalism is exhibited in recognizing transcendence as manifested through history; in affirming the human quest for truth and certainty; in the stand that is taken in history when the science is more mature and certain. Scientific realism is especially made more comprehensive and coherent when it considers the interplay of the observable and unobservable aspects of reality and of how the human person

${ }^{34}$ Nicholas Rescher, Scientific Realism: A Critical Reappraisal (Dordrecht: D. Reidel Publishing Company, 1987), 34.

${ }^{35}$ Michael Devitt, email message to author, 10 November 2014.

(c) 2020 Vida Mia S. Valverde https://www.kritike.org/journal/issue 26/valverde june2020.pdf ISSN 1908-7330 


\section{ARGUMENT FROM PSYCHOLOGICAL DIFFERENCE}

is in the scheme of things. Scientific realism is the more superior stance compared to instrumentalism because, ultimately, it makes more meaningful sense by being grounded in existing material reality that has the power to move us rather than in convenient fictions that operate on utility.

Philosophy Department, Ateneo de Davao University, Davao City, Philippines

\section{References}

BonJour, Lawrence, The Structure of Empirical Knowledge (Cambridge: Harvard University Press, 1985).

Chang, Hasok, "Epistemic Activities and Systems of Practice," in Science After the Practice Turn in the Philosophy, History, and Social Studies of Science, ed. by Léna Soler, Sjoerd Zwart, Michael Lynch, and Vincent IsraelJost (New York: Routledge, 2014).

Devitt, Michael, "A Naturalistic Defense of Realism," in Metaphysics: Contemporary Readings, ed. by S.D. Hales (Albany: Wadsworth Publishing Company, 1999). Realism and Truth (New Jersey: Princeton University Press, 1991). "Scientific Realism," in The Oxford Handbook of Contemporary Philosophy, ed. by Michael Smith and Frank Jackson (New York: Oxford University Press, 2007).

Fine, Arthur, “Unnatural Attitudes: Realist and Instrumentalist Attachments to Science," in Mind, 96 (1986).

Gardner, Michael R., "Realism and Instrumentalism in Pre-Newtonian Astronomy" in Testing Scientific Theories, ed. by John Earman, (Minneapolis: University of Minnesota, 1983).

Hacking, Ian, "Do We See Through a Microscope?" in Images of Sciences: Essays on Realism and Empiricism, ed. Paul M. Churchland and Clifford A. Hooker (Chicago: University of Chicago Press, 1985).

Representing and Intervening: Introductory Topics in the Philosophy of Natural Science (Cambridge: Cambridge University Press, 1983).

Hendry, Robin Findlay, "Are Realism and Instrumentalism Methodologically Different?" in Philosophy of Science, 68:3 (Supplement, 2001).

Ibana, Rainier R.A., Solidarity and Social Analysis (A Disseration on Max Scheler's Social Philosophy) (Quezon City: Sublime Paralytic Publications, 1993).

Kukla, André, Studies in Scientific Realism (New York: Oxford University Press, 1998).

Laudan, Larry, "A Confutation of Convergent Realism," in Philosophy of Science: The Central Issues, ed. by Martin Curd and J. A. Cover (New York: W.W. Norton \& Company, Inc., 1998). 
Leplin, Jarrett, A Novel Defense of Scientific Realism (New York: Oxford University Press, 1997).

Lonergan, Bernard J.F., Insight: A Study in Human Understanding (New York: Philosophical Library, Inc., 1956).

Massimi, Michela, "Questioning Truth, Reality, and the Role of Scientific Progress," interview by Philip Ball, in Wired (2 June 2018), $<$ https://www.wired.com/story/questioning-truth-reality-andscientific-progress/>.

Norris, Christopher, On Truth and Meaning: Language, Logic, and the Grounds of Belief (London: Continuum International Publishing Group, 2006).

Redish, Edward, "Axioms," in The Unabashed Academic (27 June 2010), $<$ http://theunabashedacademic.blogspot.com/2010 0601 archive.ht $\underline{\mathrm{ml}}>$.

Rescher, Nicholas, Scientific Realism: A Critical Reappraisal (Dordrecht: D. Reidel Publishing Company, 1987).

Sankey, Howard, Scientific Realism and the Rationality of Science (Hampshire: Ashgate Publishing Limited, 2008).

Sellars, Wilfrid Science, Perception, and Reality (New York: Humanities Press, 1962).

Smart, J.J.C., Philosophy and Scientific Realism (London: Routledge \& Kegan Paul, Ltd., 1963). 